\title{
Teaching Skills of Teacher in Increasing Student Learning Interest
}

\author{
Sariaman Gultom ${ }^{1}$, Ahmad Fakhri Hutauruk ${ }^{2}$, Andres M. Ginting ${ }^{3}$ \\ ${ }^{1}$ Lecturer in Pancasila and Civic Education Study Program, Universitas Simalungun, Indonesia \\ ${ }^{2,3}$ Lecturer in History Education Study Program, Universitas Simalungun, Indonesia \\ Sariamangultom1966@gmail.com
}

\begin{abstract}
Lack of student interest in learning results in pre-determined learning goals not being achieved. The teacher must work hard to find new breakthroughs so students are interested in learning. In addition to implementing a good work ethic, a teacher must also have skills in teaching as to achieve learning objectives in accordance with curriculum requirements. This research involves qualitative research method. The data analysis techniques used are: data reduction, data presentation and drawing conclusions / verification. The result of the study indicate that a teacher must have several teaching skills, namely: (1) questioning skills, (2) reinforcement skills, (3) variation skills, (4) explaining skills, (5) learning skills opening and closing, (6) small group discussion guiding skills, (7) small classroom management skills, and (8) small group and individual teaching skills.
\end{abstract}

Keywords skills, teachers, interest in learning

\section{Introduction}

Based on the results of observations made by researchers in several different schools in the Pematangsiantar City area, it was found that often when teachers will teach in class have problems, where these obstacles often come from students because there are still many of them who do not care about the teacher when in front class, besides that there are still many who play with their friends when the teacher starts the lesson in class. Thus, the learning process in the classroom is not conducive and does not achieve learning objectives.

In fact, in addition to being at home students can also study at school, meaning schools have an important role in the process of transferring knowledge so that students can learn what they do not know and develop their potential. As explained by Wayne (in Admodiwiro, 200: 37) explains that the school is a system of social interaction of an organization as a whole consisting of personal interactions related together in an organic relationship. The school is also an institution or place for learning such as reading, writing and learning to behave well. Schools are also an integral part of a society dealing with real conditions found in a society that are dealing with real conditions that are present in society today. School is also the second environment where children practice and grow their personalities (Zanti Arbi in Pidarta, 1997: 171).

However, the interaction carried out at school needs to be done by several parties including between teacher and students so that the interaction process goes 2 (two) directions. The teacher has an important role in the interaction process because the teacher will transfer knowledge to students. The teacher is a profession, which means a position that requires special skills as a teacher and cannot be carried out by just anyone outside the field of education. For a teacher to know and be able to apply several teaching principles in 
order to carry out their duties in a professional manner. Among them, (1) teachers must be able to arouse the attention of students on the subject matter provided and can use a variety of media and varied learning resources. (2) the teacher must be able to arouse the interest of students to be active in thinking and searching and finding their own knowledge. (3) teachers must develop students' attitudes in fostering social relations, both in the classroom and outside the classroom. (4) teachers must investigate and explore the differences in the participants individually in order to serve students in accordance with these differences (Arifudin, 2015: 180).

Thus, the teacher must be able to manage the class well. The activity of managing the class intends to create and maintain a class atmosphere (condition) so that the learning process takes place effectively and efficiently. Teachers must have teaching skills in order to achieve learning goals and students can understand what is conveyed by the teacher. Teaching skills are professional competencies that are quite complex, as an integration of various teacher competencies in their entirety and comprehensively. As explained by Turney (in Mulyasa, 2017) revealed eight teaching skills that are very instrumental and determine the quality of learning, namely the skills to ask questions, provide reinforcement, make variations, explain, open and close lessons, guide small group discussions, manage classes, and teach small groups and individuals.

Based on this background, the researcher is very interested in exploring in depth how the teacher's skills in teaching so as to attract students' interest to learn well.

\section{Research Method}

This research involves qualitative research method. As explained by Creswell (1998: 15) that Qualitative research is an inquiry process of understanding based on detailed scientific traditions of inquiry that explore a social or human problem. The researcher builds a complex, holistic picture, analyzes words, reports detailed views of informants, and conducts the study in a natural setting. Whatever the approach used is a naturalistic approach because the research is done in natural conditions (natural settings) or on natural objects. Natural objects are objects that develop as they are not manipulated by researchers and the presence of researchers does not change the dynamics of these objects (Sugiyono, 2011: 14).

The data analysis technique uses interactive model analysis. Because it is considered more appropriate to meet the requirements in conducting data analysis. Interactive analysis consists of three activities that occur simultaneously, namely: data reduction, presentation data and drawing conclusions / verification (Miles and Huberman, 1992: 16).

\section{Discussion}

Problems that often occur in class are often due to students who do not care about the teacher in front of the class which results in the learning process not going well, so the learning objectives are not achieved according to curriculum demands. How will it be realized if the students are just not interested in taking lessons in class? Therefore, teachers need to make new breakthroughs to attract students' learning interest. In addition to the teacher must master learning material, learning methods, learning models and the use of media in accordance with the material being taught, the teacher must also have skills in teaching. 
Before understanding and applying teaching skills, a teacher first understands and has a good work ethic. As explained by Sinamo (2011) that (1) Work is Grace; I Work Sincerely Gratitude, (2) Work is Trustful; I Work Right Full of Responsibility, (3) Work is a Call; I Work Completely Full of Integrity, (4) Work is Actualization; I Work Hard with Enthusiasm, (5) Work is Worship; I Work Seriously with Love, (6) Work is Art; I Work Smart Full of Creativity, (7) Work is Honor; I Work Diligently Full of Excellence and (8) Work is Service; I Work Plenary Full of Humility.

Thus it is hoped that later the learning process can run well and students have an interest in participating in learning well. The intended teaching skills are as follows:

\subsection{Questioning Skills}

Questioning skills are very important skills mastered by the teacher. This is because the ability to ask students can create a more meaningful learning atmosphere, so that the values in the learning material can be conveyed well to students. By asking questions can also provoke student knowledge of the material to be taught, based on this the teacher can explain the material according to student needs.

As explained by Supriyadi (2011: 158) questioning skills are skills that are used to get answers or feedback from others. The questioning skill is a teaching itself, because in general the teacher in his teaching always involves or uses question and answer. Thus, the questioning skills possessed by the teacher can provide stimulus to students to think in answering questions raised by the teacher.

\subsection{Strengthening Skills}

Similarly, the skills to ask questions, where students are also given a stimulus to be able to do the best in him. Skills to provide reinforcement or reinforcement in general can be interpreted as the ability of teachers to respond to student behavior in teaching and learning activities, so that students are encouraged to increase these positive behaviors. Basically the terms appreciation, prizes, praise that are often equated with reinforcement have a position as part of skills in giving reinforcement.

Giving reinforcement as a response in the process of educational interactions in the form of positive responses and negative responses. A positive response is a response given through a reward, while a negative response is given through punishment. Both have the same goal, which is to change someone's behavior. This shows that changes in student behavior (behavior modification) can be done by providing reinforcement in order to increase student motivation (Djamarah, 2005: 118).

This needs to be done by the teacher because the provision of reinforcement aims to: (1) increase student attention, (2) arouse and maintain student motivation, (3) stimulate students to think, (4) facilitate student learning, (5) encourage appropriate behavior productive, and (6) control and modify inappropriate behavior.

\subsection{Skills for Making Variations}

In general, variation skills are the teacher's skills to keep the learning climate interesting, not boring, so students show enthusiasm and perseverance, are full of enthusiasm, and actively participate in every step of the learning activities. The teacher's goal to make variations is for a specific purpose so that it can achieve what has been planned before so that it can run smoothly and continuously. Thus, teachers need to keep the learning climate conducive and pleasant. 
This is emphasized by Wina Sanjaya (2005: 166) that everyone has a boredom in learning to feel bored, bored, less passionate, even sleepy as these conditions usually arise d

ue to the presentation of your teacher who is less attractive, so you want the learning process to end quickly. To avoid students' boredom in learning, teachers need to have stimulus variation skills.

Thus, teachers need to use lectures for auditive students, teachers need to use media, visual aids for students, and teachers must hold discussions, experiments, demonstrations, and practices for kinetic students. If the teacher has done this it means the teacher has touched each student's intress. In addition, the use of variations in learning activities is intended to overcome the boredom and boredom of students due to monotonous learning, by holding variations in learning activities, it is expected that learning is more meaningful and optimal, so students always show perseverance, enthusiasm, and full participation in learning activities (Rusman, 2011: 85).

\subsection{Explanatory Skills}

The skill to explain is the presentation of information orally which is organized systematically to show the relationship between one message and another message, so that the desired understanding is reached. For example between cause and effect, definition by example or by something that is not yet known.

Explanatory skills is one of the most important aspects of the teacher's activities in his interactions with students in the classroom and usually the teacher tends to dominate the conversation and has a direct influence, for example in giving facts, ideas, or opinions. Therefore, this must be addressed to increase its effectiveness in order to achieve optimal results from the teacher's explanation and conversation so that it is meaningful for students (Usman, 2010: 89).

The teacher's aim is to provide explanations in order to: (1) guide students to be able to understand science objectively and reason, (2) train students to always concentrate on listening to the teacher's explanation so that it involves them to think while solving problems or questions, (3 ) To get responses and feedback from students regarding their level of understanding and to overcome their misunderstanding and (4) Guide students to appreciate and get a process of reasoning by using evidence in solving the problem.

\subsection{Skills for Opening and Closing Lessons}

Skills to open lessons or set induction is an effort made by the teacher in learning activities to create preconditions for students so that mental and attention are focused on the learning experience that is presented so that it will easily reach the expected competence, meaning the activities carried out by the teacher to create an atmosphere ready mentally and raises attention so students focus on the things they will learn. While closing the lesson is basically the activities carried out by the teacher to end the core learning activities.

This is confirmed by Djamarah (2010: 138-139) that opening and closing lessons can be done on lessons, both long and short, small parts of the whole material or part by part of a concept. It also can be done on students who are small groups, individuals or large groups. Good teacher criteria when opening a lesson, such as: arouse curiosity, enthusiastic attitude, provide variations of learning also make a connection with previous learning. Efforts made by the teacher when closing the lesson, such as: activities provide a comprehensive picture of what students have learned and provide a picture (to find out the relationship) between the experience that has been mastered with the things that have just 
been learned. Based on the opinion above, it can be concluded that the skills of opening and closing lessons are very important as the key to the success of teachers in achieving the desired goals and to find out the level of achievement of teachers' success in the learning process (Supriatna and M Arif, 2015: 67-68).

\subsection{Skills in Guiding Small Group Discussions}

Mulyasa in Suwarna (2006: 79), "group discussion is a process regular conversation, which involves a group of people in face-to-face interactions free and open, with the aim of sharing information / experience, making decisions or solve a problem." This needs to be done by the teacher considering that group discussion is a strategy that allows students to master a concept or solve a problem through a process that gives opportunities to think, interact socially, and practice being positive. Thus group discussions can enhance student creativity, as well as foster communication skills including language skills.

This was confirmed by Rusman (2013: 89) who stated that the skill of guiding small group discussions is one way that can be done to facilitate the learning system needed by students as a group. For this reason teacher skills must be trained and developed, so that teachers have the ability to serve students in small group learning activities. Thus, the teacher must have the skills to guide small group discussions in order to carry out small group discussions effectively in order to achieve learning objectives.

\subsection{Classroom Management Skills}

Classroom Management Skills is an effort made by the teacher in order to create conducive learning conditions so that the learning process can run efficiently and effectively. This needs to be done by the teacher because learning requires high concentration so a class atmosphere must be created that can increase student interest in learning. The purpose of classroom management is that every child in the class can learn in an orderly manner so that the teaching objectives are achieved effectively and efficiently.

This was confirmed by Usman (2010: 90) who stated that there was a disturbance, an inability to adjust. The skill to manage an effective classroom is an absolute prerequisite for the occurrence of absolute conditions for an effective teaching and learning process. As well as a good relationship between the teacher and students and between students and students is a prerequisite for successful classroom management. At the same time an optimal learning condition is achieved if the teacher is able to manage students and infrastructure and is able to control it in a pleasant atmosphere to achieve teaching objectives.

The objectives of classroom management are as follows: (1) creating and maintaining optimal learning conditions, (2) returning optimal learning conditions, (3) encouraging students to develop individual responsibilities for their behavior, (4) building students to understand behavior in accordance with classroom rules, and understands that the teacher's reprimand is a warning and not anger and (5) creates a sense of obligation to involve themselves in assignments and to behave in accordance with class activities.

\subsection{Small Group and Individual Teaching Skills}

Essentially small group and individual teaching skills are intrapersonal relationships between teacher and student and also students and students. In this skill, students learn according to their level of ability and ability. In addition, students are also involved in planning teaching and learning activities.

Basically, small group and individual teaching skills can be said to be teaching which gives more opportunities to students in the sense of reducing the role of the teacher in the 
classroom. These skills will enhance the understanding of the teacher and students involved, as well as understanding in organizing teaching and learning or educational interactions. Interpersonal and social relationships, and organizing are important for the success of teaching small groups and individuals. Therefore teachers must have the ability to do personal relationships, if they want to apply the teaching skills of small groups and individuals (Nasrul, 2012: 71-72).

Thus the skills of teaching small groups and individuals can be done by: (1) Developing skills in organizing, by providing motivation and making variations in the assignment of tasks, (2) Guiding and facilitating learning, which includes reinforcement, initial process, supervision, and learning interactions, (3) Planning the use of space and (4) Giving clear, challenging, and interesting tasks.

\section{Conclusion}

Based on the results of research and discussion of teacher skills in teaching can increase student interest in teacher learning, it can be seen that a teacher must have some of the skills described, namely: (1) asking questions, (2) strengthening skills, (3) holding skills variations, (4) explaining skills, (5) opening and closing lessons, (6) small group discussion guiding skills, (7) classroom management skills, and (8) small and individual group teaching skills.

The implementation of teaching skills is expected to attract students 'interest in learning better, more conducive classroom conditions and students' readiness to accept learning material taught by teachers so that learning objectives can be achieved in accordance with curriculum demands.

\section{References}

Admodiwiro, Soebagio. (2000). Manajemen Pendidikan. Jakarta: PT. Ardadizya

Arifudin, Iman Syahid. (2015). Peranan Guru Terhadap Pendidikan Karakter Siswa di Kelas V SDN 1 Siluman. Bandung: Jurnal Pedadidaktika Vol (2) No (2) https://ejournal.upi.edu/index.php/pedadidaktika/article/download/5844/3951 .

Creswell, W. John, (1998). Qualitative Inquiry and Research Design: Choosing Cataloging Among Five Tradition. London: Sage Publication Inc

Djamarah, Syaeful Bahri (2005). Guru dan Anak Didik dalam Interaksi Anak Didik. Jakarta: Rineka Cipta

Djamarah, Syaiful Bahri. (2010). Guru dan Anak Didik Dalam Interaksi Edukatif (Suatu Pendekatan Teoretis Psikologi). Jakarta: Rineka Cipta. 